\title{
Profil Pemecahan Masalah Matematika Siswa Ditinjau dari Gaya Kognitif Reflektif dan Impulsif
}

\author{
Imam Muhtadi Azhil ${ }^{1}$, Agustin Ernawati ${ }^{1}$, Moch. Lutfianto ${ }^{1}$ \\ ${ }^{1,2,3}$ Jurusan Pendidikan Matematika STKIP Al Hikmah Surabaya \\ Jl. Kebonsari Elveka V Surabaya
}

\begin{abstract}
This research aims to explain the ability of problem-solving between reflective cognitive and impulsive cognitive students. The subject of this research is students of class VII C SMP Al-Hikmah Surabaya. Subject chose based on a test of cognitive style, one student of reflective cognitive style and one student of impulsive cognitive style. The instrument uses a test of the MFF (Matching Familiar Figures) and tests the ability to problemsolving of ratio. The subject of reflective cognitive style can retell the problems that exist in the problem, said, write down the steps used in the settlement of a matter, carry out all settlement plan as a whole and coherent, and provide settlement solutions at the end of time. The subject of impulsive cognitive style, the average can tell, mention, write on some matter, of course, does not implement the settlement plan, not coherent, and settlement in a hurry.
\end{abstract}

Keywords: Reflective cognitive style; Impulsive cognitive style; comparative; Problem-solving

\section{PENDAHULUAN}

Matematika sering dianggap sulit, membosankan dan tidak menarik. Hal ini dikarenakan matematika merupakan mata pelajaran yang sering kali permasalahannya komplek dan seringkali dibuat dalam bentuk soal cerita (Muttaqien, 2013). Menurut Siswono (2008) masalah dapat diartikan sebagai situasi atau pertanyaan yang dihadapi seseorang individu atau kelompok ketika mereka tidak mempunyai aturan atau prosedur tertentu yang segera dapat digunakan untuk menentukan jawabannya. Ciri-ciri situasi atau pertanyaan dapat disebut sebagai masalah. Pertama, individu menyadari atau mengenali suatu situasi atau pertanyaan yang dihadapi. Kedua, individu merasa perlu mengambil tindakan untuk megatasi situasi tersebut. Ketiga, tidak segera dapat ditemukan cara mengatasi situasi tersebut, sehingga diperlukan suatu usaha untuk mendapatkan cara yang dapat digunakan untuk mengatasinya.

Penyelesaian masalah memerlukan pemahaman dan penalaran yang lebih mendalam. Salah satu kemampuan penalaran yang dibutuhkan adalah proses berpikir siswa tingkat tinggi dalam menentukan bagaimana cara memecahkan masalah 
matematika. Siswa yang terampil dalam pemecahan masalah akan mampu berpacu dengan kebutuhan hidupnya, menjadi pekerja yang lebih produktif dan memahami isuisu kompleks yang berkaitan dengan masyarakat global (Jazuli, 2016). Latar belakang atau alasan seseorang perlu belajar memecahkan masalah matematika yaitu adanya fakta bahwa orang yang mampu memecahkan masalah akan hidup dengan produktif dalam abad 21 ini.

Pemecahan masalah tidak hanya bergantung pada jawaban akhir tetapi bagaimana proses berpikir siswa dalam menyelesaikan masalah matematika. Kemampuan pemecahan masalah tentu tidak dimiliki seseorang secara langsung, melainkan perlu dipelajari dan dilatih, salah satunya melalui pembelajaran matematika.

Polya (1973) menjelaskan bahwa pemecahan masalah sebagai suatu usaha mencar jalan keluar dari suatu kesulitan guna mencapai suatu tujuan yang tidak begitu mudah dapat segera dicapai. Tahapan pemecahan masalah dibagi menjadi 4 tahap penting yaitu: (1) memahami masalah (understanding the problem), (2) membuat rencana (devising a plan), (3) melaksanakan rencana (carrying out the plan), (4) memeriksa kembali (looking back) (Muttaqien, 2013).

Pada tahap memahami masalah siswa dihadapkan pada beberapa pertanyaan: (a) Apakah kamu mengerti semua kata-kata/kalimat dalam soal? (b) Dapatkah kamu menyatakan masalah dalam kalimat sendiri? (c) Apakah kamu mengetahui apa yang diketahui? (d) Apakah kamu mengetahui apa yang ditanyakan? (e) Apakah informasi yang tersedia cukup? (f) Apakah terdapat informasi tambahan? (g) Apakah ada masalah serupa yang sudah pernah diselesaikan?. Pada tahap membuat rencana, siswa menghadapi pertanyaan "Di antara strategi berikut, manakah yang dapat digunakan untuk menyelesaikan masalah?" (a) Menduga dan memeriksa, b) Menggunakan variabel, (c) Membuat gambar, (d) Melihat pola, (e) Membuat daftar, (f) Menyelesaikan masalah yang lebih sederhana, (g) Membuat diagram, (h) Menggunakan penalaran langsung, (i) Menggunakan penalaran tidak langsung, (j) Menggunakan sifat-sifat bilangan, (k) Menyelesaikan masalah yang ekivalen, (l) Bekerja mundur, (m) Menggunakan kasus, (o) Menyelesaikan suatu persamaan, (p) Mencari rumus, (r) Melakukan simulasi, (s) Menggunakan model, (t) Menggunakan analisis dimensional, (t) Mengidentifikasi sub tujuan, (u) Menggunakan koordinat, dan (v) Menggunakan sifat simetri. 
Pada tahap melaksanakan rencana, siswa melakukan kegiatan: (a) Melaksanakan strategi atau strategi-strategi yang telah dipilih sampai masalah terpecahkan atau sampai suatu tindakan baru dianjurkan, (b) Menggunakan sedikit waktu untuk berpikir. Jika tidak dapat memecahkan masalah sendiri, mintalah petunjuk pada yang lain atau tinggalkan masalah untuk sementara, dan (c) Tidak takut untuk memulai lagi. Seringkali, permulaan yang baru dan strategi yang baru membawa pada kesuksesan. Pada tahap terakhir, yakni memeriksa kembali, siswa dihadapkan pada pertanyaan berikut; (a) Apakah penyelesaian sudah benar? Apakah penyelesaian memenuhi persyaratan dalam masalah? (b) Apakah ada penyelesaian yang lebih mudah? (c) Apakah dapat dilihat bahwa penyelesaian yang diperoleh dapat digeneralisasikan pada kasus yang lebih umum?.

Setiap individu memiliki karakteristik yang berbeda dengan individu lain pada saat memecahkan masalah. Menurut Suharman (2005), perbedaan karakteristik dapat meliputi perbedaan cara menerima, mengorganisasikan, dan mengolah suatu informasi yang diterima. Hal inilah yang disebut dengan istilah gaya kognitif. Gaya kognitif reflektif dan implusif merupakan gaya kognitif yang menunjukkan tempo atau kecepatan dalam berpikir, maka ide untuk menyelesaikan pemecahan masalah tergantung gaya kognitif yang dimiliki oleh siswa (Fadiana, 2016). Pada kenyataannya, dalam pembelajaran matematika ditemukan siswa yang cepat merespon masalah matematika yang diberikan tanpa berpikir secara mendalam sehingga jawaban cenderung salah (Rahmatina, 2014). Selain itu, ada juga siswa yang lambat merespon masalah metematika yang diberikan dan jawabannya cenderung benar. Hal ini yang mendorong untuk mendeskripsikan bagaimana "profil pemecahan masalah matematika siswa ditinjau dari gaya kognitif reflektif dan implusif".

\section{METODE PENELITIAN}

Penelitian ini merupakan penelitian deskriptif dengan menggunakan pendekatan kualitatif. Sesuai dengan permasalahan, maka tujuan penelitian ini adalah untuk menganalisa, mendeskripsikan pendapat para parstisipan penelitian atau informan peneliti. Penelitian dilaksanakan di SMP Al Hikmah Surabaya tahun pelajaran 2016/2017 pada materi perbandingan.

Subjek sebagai sumber data dipilih secara snowball sampling. Subjek-subjek yang 
dimaksud adalah siswa kelas VII C SMP Al Hikmah Surabaya yang memiliki gaya kognitif refleksif dan impulsif. Penentuan subjek penelitian yang memiliki gaya kognitif reflektif dan impulsif dilakukan dengan cara menyebarkan angket penelitian kepada siswa yang berupa tes MFF (Mathcing Familiar Figures). Selanjutnya, dipilih 2 siswa berdasarkan kemampuan gaya kognitif dengan rincian seorang siswa dengan gaya kognitif implutif dan seorang siswa dengan gaya kognitif reflektif.

Teknik analisis data menggunakan teknik analisis data Miles (1992). Tahap pertama dimulai dengan mereduksi data yang berupa hasil wawancara. Kemudian data tersebut disajikan dalam bentuk teks naratif. Setelah semua dilakukan maka dapat ditarik kesimpulan pemecahan masalah matematika siswa dalam menyelesaikan soal perbandingan berdasarkan gaya kognitif.

Tahap kedua yaitu menganalisa data, dilakukan dengan menggambar secara umum hasil penelitian mulai dari lokasi penelitian sampai dengan mendeskripsikan hasilnya. Tahap ketiga membuat kesimpulan, merupakan sebuah proses untuk mencari serta menyusun secara sistematik data yang diperoleh dari hasil angket, tes, dan wawancara. Hal yang dilakukan yaitu dengan cara mengorganisir data ke dalam kategori, menjabarkan ke dalam unit-unit, melakukan sintesa, menyusun ke pola, memilih mana yang penting dan akan dipelajari, membuat kesimpulan sehingga mudah dipahami oleh diri sendiri maupun orang lain.

\section{HASIL DAN PEMBAHASAN}

Hasil tes MFF (Matching Familiar Figure) diurutkan berdasarkan waktu siswa dalam menyelesaikan masalah matematika, mulai waktu yang tercepat sampai terlama. Hal ini untuk menentukan subjek yang termasuk kategori gaya kognitif refleksif dan gaya kognitif impultif. Dari 30 siswa diperoleh karakteristik masing-masing gaya kognitif siswa. Adapun hasil tes MFF disajikan pada Tabel 1.

\section{Tabel 1.}

Hasil Tes MFF

\begin{tabular}{lc}
\hline \multicolumn{1}{c}{ Kategori } & Jumlah \\
\hline Cepat dan cenderung benar & 3 \\
Cepat tapi cenderung Salah (Implusif) & 14 \\
Lambat tapi cenderung benar (Reflektif) & 9 \\
Lambat cenderung salah & 4 \\
\hline
\end{tabular}


Berdasarkan Tabel 1 tampak bahwa terdapat 14 siswa memiliki gaya kognitif implusif, 9 siswa memiliki gaya kognitif reflektif, dan 7 siswa tidak termasuk gaya kognitif reflektif dan gaya kognitif implusif. Selanjutnya, dipilih 2 subjek untuk di analisis kemampuan gaya kognitifnya, masing-masing dipilih seorang siswa gaya kognitif reflektif dan seorang siswa gaya kognitif implusif. Siswa dengan gaya kognitif reflektif diberi simbol subjek 1 (S1), sedangkan siswa dengan gaya kognitif impulsif diberi simbol subjek 2 (S2).

\section{Pemecahan Masalah Subjek 1}

Pada tahap memahami masalah, subjek 1 dapat menyebutkan dan dan menuliskan apa yang diketahui dan apa yang ditanyakan dalam soal dengan tepat. Seluruh informasi yang ada di soal dituliskan dengan kalimatnya sendiri berdasarkan materi yang telah diketahui. Adapun petikan wawancara subjek 1 terkait dengan tahapan memahami masalah sebagai berikut:

P: $\quad$ Apakah saudara dapat memahami soal yang diberikan?

S1: Saya dapat memahami apa yang diminta dalam soal dan informasi yang terdapat pada soal.

Pada tahap membuat rencana penyelesaian, subjek 1 dapat menyebutkan dan menuliskan langkah-langkah yang digunakan untuk menyelesaikan soal perbandingan. Selain itu, subjek 1 menyebutkan seluruh informasi yang dimiliki yang bisa digunakan untuk menyelesaikan masalah yang ada. Subjek 1 tidak membutuhkan informasi lain karena berdasar dari yang dimiliki, subjek 1 sudah bisa menemukan jawabannya.

Pada tahap melaksanakan rencana penyelesaian, subjek 1 sudah melaksanakan semua langkah yang telah ditulis pada lembar jawaban. Selain itu, subjek 1 lebih teliti dan berhasil menjawab dengan jawaban yang benar. Adapun petikan wawancara subjek 1 terkait dengan tahapan melaksanakan rencana sebagai berikut:

$P$ : Bagaimana cara Anda untuk menyelesaikan soal yang diberikan?

S1: Pertama, saya menuliskan informasi yang terdapat pada soal, kedua saya menuliskan konsep perbandingan, ketiga saya mengerjakan secara runtut mulai dari rumus sampai hasil akhir.

$P$ : Apakah saudara mengerjakan soal secara terburu-buru?

S1: Tidak, saya mengerjakan dengan tenang dan konsentrasi, sebab saya menginkan jawaban saya sempurna dan benar walaupun membutuhkan waktu yang lama.

Pada tahap memeriksa kembali, subjek 1 dapat memeriksa keseluruhan jawaban yang dikerjakan, walaupun tidak semua jawaban berhasil dijawab dengan benar. Selain 
itu, subjek 1 memeriksa jawaban dengan teliti dan membutuhkan waktu yang sangat lama sehingga dia dapat membenarkan jawaban yang salah di akhir pengerjaan. Berdasarkan hasil pengerjaan subjek 1, dari 4 soal diperoleh 3 jawaban yang benar. Adapun petikan wawancara subjek 1 terkait dengan tahapan memeriksa kembali sebagai berikut:

P: Apakah saudara yakin dengan jawabannya?

S1: Yakin, karena saya mengerjakan secara hati-hati dan teliti kembali setelah selesai mengerjakan.

Berdasarkan hasil petikan wawancara di atas dapat disimpulkan bahwa subjek 1 dalam mengerjakan soal lebih cenderung berhati-hati. Hal ini dikarenakan mereka menginginkan jawaban yang sempurna walaupun waktunya lebih lama. Selain itu, subjek 1 menyatakan dalam mengerjakan soal lebih senang mengerjakan secara runtut sampai jawaban akhir ditemukan serta membaca informasi yang terdapat dalam soal lebih teliti.

\section{Pemecahan Masalah Subjek 2}

Pada tahap memahami masalah, subjek 2 dapat menceritakan kembali permasalahan yang ada dengan menggunakan kata sendiri pada beberapa soal tertentu saja. Hal-hal yang diketahui dan ditanyakan dari soal, subjek 2 hanya dapat menyebutkan beberapa informasi yang ada dalam soal baik melalui wawancara dan tulisan jawaban pada lembar jawaban. Adapun petikan wawancara subjek 2 terkait dengan tahapan memahami masalah sebagai berikut:

P: $\quad$ Apakah saudara dapat memahami soal yang diberikan?

S2: Saya dapat memahami apa yang diminta oleh soal, tetapi ada informasi yang belum saya dimengerti.

Pada tahap membuat rencana penyelesaian, subjek 2 dapat menyebutkan dan menuliskan pada beberapa soal saja. Selain itu, berkaitan dengan cukup tidaknya informasi yang diberikan di soal untuk menjawab pertanyaan yang ada. Subjek 2 menyebutkan memiliki kebingungan dengan soal yang diberikan, sehingga cukup kesulitan untuk menyelesaikan soal yang diberikan.

Pada tahap melaksanakan rencana penyelesaian, subjek 2 dapat melaksanakan rencana penyelesaian hanya sebagian saja, sehingga hasilnya cenderung salah. Ada beberapa soal yang tidak diselesaikan dengan sempurna. Adapun petikan wawancara subjek 2 terkait dengan tahapan melaksanakan rencana sebagai berikut: 
P: Bagaimana cara untuk menyelesaikan soal yang diberikan?

S2: Saya langsung mengerjakan soal dengan cara yang saya ketahui tanpa menuliskan konsep perbandingan

P: $\quad$ Apakah saudara mengerjakan soal secara terburu-buru?

S2: Saya lebih senang mengerjakan secara cepat dengan waktu yang singkat. Sebab, setelah itu saya dapat mengerjakan soal yang selanjutnya.

Pada tahap memeriksa kembali, subjek 2 hampir memeriksa keseluruhan tetapi dia tergesa-gesa sehingga hampir keseluruhan jawaban kurang sempurna. Berdasarkan pengerjaan subjek 2, dari 4 soal hanya diperoleh 1 jawaban yang benar. Adapun petikan wawancara subjek 2 terkait dengan tahapan memeriksa kembali sebagai berikut:

P: Apakah saudara yakin dengan jawabannya?

S2: Belum yakin semua, karena ada beberapa soal yang saya tidak pahami.

Berdasarkan hasil petikan wawancara di atas dapat disimpulkan bahwa subjek 2 menyatakan lebih senang mengerjakan soal secara ringkas dan cenderung langsung jawaban akhir. Selain itu, subjek 2 menginginkan pengerjaan dengan waktu yang sangat singkat.

Hal di atas menunjukkan bahwa siswa bergaya kognitif implusif membutuhkan waktu yang relatif lebih singkat dari pada siswa bergaya kognitif reflektif dalam menyelesaikan soal perbandingan. Karakteristik lainya dari siswa implusif adalah penyelesaian yang dihasilkan cenderung salah, dan kurang teliti. Siswa implusif cenderung tidak melalui tahap merencanakan penyelesaian, kertas perhitungannya cenderung hanya sedikit. Selain itu, tidak mau memeriksa kembali penyelesaian yang telah dikerjakan. Beda halnya dengan siswa yang bergaya kognitif reflektif, mereka membutuhkan waktu yang lebih lama dalam menyelesaikan soal yang diberikan. Membaca dan memahami masalah secara berulang kali, merencanakan penyelesaian dengan cara merancang dan menuliskan rumus serta melakukan perhitungan pada kertas jawaban yang diberikan. Setelah itu, mereka baru menuliskan penyelesaian pada lembar jawaban. Siswa yang reflektif akan memeriksa kembali bahkan berulang kali penyelesaian yang dikerjakan.

\section{SIMPULAN DAN SARAN}

Pada tahap memahami masalah, siswa dengan gaya kognitif reflektif dapat menceritakan kembali permasalahan yang ada dengan menggunakan kata sendiri, dapat menyebutkan dan menuliskan hal-hal yang diketahui dan ditanyakan. Pada tahap 
membuat rencana penyelesaian, siswa dengan gaya kognitif reflektif dapat menyebutkan dan menuliskan langkah-langkah penyelesaian yang digunakan, serta menyebutkan bahwa informasi yang diberikan sudah cukup untuk menjawab pertanyaan yang ada. Pada tahap melaksanakan rencana penyelesaian, siswa dengan gaya kognitif reflektif dapat menyelesaikan masalah sesuai dengan rencana yang telah dibuat walaupun ada sedikit kendala dalam perhitungan dan menuliskan jawaban serta perhitungannya dengan runtut dan menggunakan bahasanya sendiri meskipun belum disertai penjelasan yang jelas. Pada tahap memeriksa kembali, siswa dengan gaya kognitif reflektif masih melakukan lebih dari satu kesalahan perhitungan, serta dapat memberikan solusi jawabannya di waktu akhir penyelesaian.

Pada tahap memahami masalah, siswa dengan gaya kognitif impulsif dapat menceritakan kembali permasalahan yang ada dengan kata sendiri pada beberapa soal saja, serta dapat menyebutkan hal-hal yang diketahui soal meskipun tidak dituliskan pada lembar jawaban. Pada membuat rencana penyelesaian, siswa dengan gaya kognitif impulsif dapat menyebutkan informasi yang diberikan tidak cukup untuk menjawab pertanyaan yang ada dan menuliskan langkah-langkah penyelesaian yang dia digunakan pada beberapa soal saja. Pada melaksanakan perencanaan penyelesaian, siswa dengan gaya kognitif impulsif dapat menyelesaikan masalah sesuai dengan rencana yang telah dibuat pada soal pada semua soal, walaupun akhirnya cenderung salah dan tidak dapat menuliskan jawaban serta perhitungannya secara runtut. Pada tahap memeriksa kembali, siswa dengan gaya kognitif impulsif memeriksa keseluruhan pada semua jawaban saja secara tergesa-gesa dan tidak dapat memberikan solusi jawabanya di waktu akhir jawabannya.

Berdasarkan hasil penelitian bahwa ada perbedaan kemampuan antara siswa yang bergaya kognitif reflektif dan siswa yang bergaya kognitif implusif dalam menyelesaikan soal perbandingan. Siswa yang bergaya kognitif reflektif mempunyai nilai rata-rata $75 \%$ dapat menyelesaikan soal perbandingan dengan benar. sedangkan siswa yang bergaya kognitif implusif mempunyai nilai rata-rata $25 \%$ dapat menyelesaikan soal perbandingan dengan benar. Perbedaan nilai rata-rata ini disebabkan karakteristik dari siswa reflektif dalam menyelesaikan soal perbandingan dalam waktu relatif lama dan cenderung berhati-hati. Selain itu, siswa reflektif cenderung melalui tahap tahap merencanakan penyelesaian, kertas jawaban cenderung banyak tahap 
penyelesaian, serta memeriksa kembali penyelesaian yang telah dikerjakan.

Penelitian ini masih terdapat kelemahan, oleh karena itu terdapat saran-saran untuk peneliti selanjutnya, antara lain: (1) penelitian ini tidak memberikan perlakuan, tetapi hanya memberikan tes kepada subjek untuk mengetahui kemampuan menyelesaikan soal perbandingan, oleh karena itu dalam melatihkan pemecahan masalah diperlukan penerapan dalam proses pembelajaran matematika, (2) subjek penelitian ini hanya dilakukan pada siswa laki-laki saja, oleh karena itu dalam penelitian selanjutnya dapat diperhatikan pada perbedaan gender, (3) hasil penelitian ini memperoleh bahwa terdapat perbedaan gaya kognitif siswa, oleh karena itu perlu diperhatikan perbedaan gaya kognitif siswa dalam pengajaran yang sudah dilakukan oleh guru.

\section{DAFTAR RUJUKAN}

Fadiana, M. (2016). Perbedaan kemampuan menyelesaikan soal cerita antara siswa bergaya kognitif reflektif dan implusif. Journal of Research and Advances in Mathematics Education, 1(1), 79-89.

Jazuli, M., \& Khabibah, S. (2015). Profil pemecahan masalah matematika kontekstual siswa SMP ditinjau dari gaya kognitif reflektif dan impulsif. MATHEDunesa, 1(4).

Miles, M. H. (1992). Analisis data kualitatif. Jakarta: Universitas Indonesia.

Muttaqien, A. (2013). Pembelajaran word problem dengan pemecahan masalah Polya di SMAN 2 Sampit. Prosiding Konferensi Nasional Pendidikan Matematika V, Himpunan Matematika Indonesia, Universitas Negeri Malang, 51-61.

Polya, G. (1973). How to solve it: A new aspect of mathematical method. Princeton University Press.

Rahmatina, S., Sumarmo, U., \& Johar, R. (2014). Tingkat berpikir kreatif siswa dalam menyelesaikan masalah matematika berdasarkan gaya kognitif reflektif dan impulsif. Didaktik Matematika, 1(1).

Siswono, T Y E. (2008). Model pembelajaran matematika berbasis pengajuan dan pemecahan masalah untuk meningkatkan kemampuan berpikir kreatif. Jurnal Surabaya: UNESA University Press.

Suharman. (2005). Psikologi kognitif. Surabaya: Srikandi. 